\title{
Civic and Citizenship Education in Denmark 1999- 2019: Discourses of Progressive and Productive Education
}

\author{
Jens Bruun
}

\begin{abstract}
This chapter addresses the participation of Denmark in IEA's Civic Education Study (CIVED) 1999, International Civic and Citizenship Education Study (ICCS) 2009, and ICCS 2016. The first sections present the Danish implementation of civic and citizenship education as a whole school approach and describes changes to this tradition during the period 1999-2019 in school policy and in teacher training. Examples of how the main national results of these IEA studies have been perceived and used are also discussed. The final sections of the chapter address how different education discourses have played an important role for public school debate, for school policymaking, and for educational research. Finally, it is discussed how general changes in school policy, without officially being labelled as changes to civic and citizenship education, have implications for the school as a place for civic and citizenship education.
\end{abstract}

\section{Danish Participation in CIVED 1999, ICCS 2009, and ICCS 2016}

Since joining the International Association for the Evaluation of Educational Achievement (IEA) Civic Education Study (CIVED) late in 1998, Denmark has participated in the CIVED 1999 study (including testing upper secondary students in 2000) and International Civic and Citizenship Education Study (ICCS) 2009 and ICCS 2016. The current author (The Danish School of Education, Aarhus University) was a major researcher in both CIVED studies and national research coordinator (NRC) in both ICCS studies.

\section{Description of Civic and Citizenship Education in Lower Secondary School}

By tradition (and law), civic and citizenship education (CCE) in Denmark is based on a whole school approach, i.e., a combination of curricular, cross-curricular, and non-curricular components. In ICCS 2016, 93\% of the Danish students attended a school whose principal reported that CCE is a matter for teachers teaching within the humanities/social science-related subjects. For $81 \%$ of the students CCE is a whole school approach, for 70\% CCE is a separate subject, and for 68\% CCE is a part of all subjects (Schulz et al. 2018a).

However, the way school principals implement CCE depends on how they value its different components. A Danish tradition for progressive education (especially from about 1975 to 1999) linked CCE to the German tradition of "Bildung" (education as a personal and cultural maturation in the process of human development). This dimension of school is often captured in the concept "democratic Bildung" ("demokratisk dannelse" in Danish) as the essence of the CCE whole school approach. It is a common perception that this ethos still plays a major role in Danish schools. However, in official curricula guidelines, CCE-related aspects tend to be introduced in a more academic sense (if mentioned at all). It is evident from ICCS 2016 that the majority of students attend a school where the principal tends to view knowledge as more important for CCE than the promotion of engagement, participation, and values (Schulz et al. 2018a, p. 34). This is probably to avoid the normative and moral dimensions of CCE (and the specter of political indoctrination).

Jens Bruun, Danish School of Education, Department of Educational Sociology, Copenhagen, Denmark email: jebr@edu.au.dk

(C) IEA International Association for the Evaluation of Educational Achievement 2021 
On the national level, the "Folkeskole" is the Danish name for the public municipal primary and lower secondary school; all these schools share standard requirements concerning the subjects to be taught ${ }^{1}$ and the leadership and organization of the schools. The Education Act for the Folkeskole states that the school "must prepare the pupils for participation, joint responsibility, rights and duties in a society with freedom and democracy. Therefore, the functioning of the school must be marked by freedom of spirit, equal worth and democracy" (Retsinformation 2017, §1,3).

The law does not provide details about implementation, and CCE is not an explicit content domain in the curriculum guidelines in lower secondary school. To some degree, this is appropriate for the whole school approach since CCE is very much an implicit dimension across different subjects and the school in general.

In grades 8 and 9, students attend "Samfundsfag" (i.e., "society subject") or social science including sociology, political science, and economics. The Ministry of Education recommends that students in these grades receive two social science lessons (of 45 minutes) per week per school year. This subject used to be "Samtidsorientering" ("contemporary society"), introduced in the Public School Act in 1975 (Struwe 1977). In 1993, samtidsorientering became social science for grade 9 and was made mandatory for grades 8 and 9 in 2005 (Ministry of Education 2006). Social science covers many aspects outlined in the ICCS framework (Schulz et al. 2016), especially within the content domain about society and political systems. The purpose of social science is to develop students' competences to take an active part in democratic society and to promote critical thinking and core personal values. These content domains are mandatory (EMU 2017):

(1) Politics: democracy, the political system, parties, ideologies, media and politics, the European Union and Denmark, international politics

(2) Economy: private finance, consumer behavior, welfare states, the market economy, sustainability

(3) Social life and culture: socialization, culture, social differentiation (equality and inequality)

(4) Methods: communication, information gathering, statistics

The subject is intended as an introduction to social science as a set of scholarly disciplines with three dimensions: political, social, and cultural. There are no requirements prioritizing local, national, regional, or global dimensions. In 2006, the Ministry of Education decided that social science should not include the relationship between man and nature and that sustainability in social science should be introduced in the context of the topic of economic growth. This was a part of revisions where the Ministry gave the subject a more academic rather than normative profile (Kaare 2006).

Social science is one of six humanities/social science subjects that do not have compulsory tests. Instead, each school year after grade 9, one of these subjects is drawn by lottery for examination. If social science is drawn, students must prepare a product (for example, a movie, a poster, or an article) about a self-chosen problem to be examined in an oral examination (Ministry of Education 2018a). The most recent guidelines highlight two ways of teaching social science: the open school method and problem-oriented project work. These methods entail visits to and cooperation with relevant institutions and/or students investigating topics outside school (Ministry of Education 2018b).

The Ministry of Education guidelines for other subjects include very little explicit CCE-related information. The guidelines for the subject of Danish include some content objectives potentially

1 In Denmark some schools are so-called "private schools" or "free schools." They must measure up to the same standards as public schools. 
relevant to CCE, such as the promotion of personal and cultural identity and the students' aesthetical, ethical, and historical understanding. However, explicit political, civic, and democratic content dimensions are not included. Some historical, national, cultural, religious, or economic aspects of other subjects may be taught in ways relevant to CCE. Two examples from the history subject are the study of the Danish constitution of 1849 and women's right to vote (1915).

A number of topics and themes are defined as supplementary tasks. Some of these can be regarded as having CCE-related content, even though they are not officially defined as parts of CCE. There are three so called "mandatory topics," but with no mandatory number of lessons attached to them: traffic education; health, sex, and family knowledge; education and occupation. They must all be included in one or more of the existing mandatory subjects from grade 1 to grade 9. The school principal decides in which subjects they should be included. In addition, there are three so called "mandatory cross-subject themes": innovation and entrepreneurship; IT and media; development of language skills. These must be integrated into and across the existing mandatory subjects and are included in ministerial guidelines for the subjects (Ministry of Education 2018c, 2018d).

In 2015, 2017, and 2019 the Danish Ministry of Education and the National Parliament held mock parliamentary elections for grades 8 to 10 in cooperation with The Danish Youth Council (Ministry of Education 2017a). This is not mandatory, but many schools participated. The Ministry's archive of reports, guidelines, and recommendations from 1995-2018 reveals little about CC. An exception is a book called Learning Democracy (in English) containing examples of CCE-related school projects (Ministry of Education 2008).

There is a relatively long tradition in Denmark for student councils in Folkeskolen. Since 1986, students have had the right to form a Student Council at any school with five or more grade levels (Christensen and Olsen 2013). It is a common perception (and often a fact) that Student Councils have very limited real influence, yet this varies considerably, because local school authorities are relatively free to decide how student councils function and the extent of their influence (Retsinformation 2014).

\section{Civic and Citizenship Education in Danish Teacher Education}

CCE at school is mainly perceived as a whole school approach involving all teachers and all subjects. However, some teachers of social science may be seen as specialists: In the school year 2017/2018 almost $82 \%$ of the teachers teaching social science studied social science as part of their teacher training (Styrelsen for IT og Læring 2018).

There are no requirements with regard to CCE training for teachers in general. However, there is a compulsory subject in the teacher-training program called "Christianity, life-enlightenment and citizenship," which provides insight into religion and culture, the history of ethics, along with democracy and citizenship. This subject is part of basic subjects intended to provide teachers with general professional competences. It is mandatory for all teacher-training programs to offer this subject, which has eight knowledge goals. Three of these relate to Christianity/religion, two to ethics and philosophy, and three to human rights, citizenship, and democratic principles. In other words, the foundation of politics or democracy as a secular matter is not particularly strong. Ethical questions are posed within a complex context with religious perspectives on one side and political perspectives on the other. Democracy is dealt with as a part of a broad cultural heritage, including the (alleged) co-development of Christianity and democracy in Denmark. The subject appears to be implemented in somewhat different ways in different teacher-training institutions. 


\section{Changes to Democratic Aspects of the Folkeskole and Teacher Education (1999-2019)}

Apart from the development of social science as a school subject, between 1999 and 2019, there have been no major curriculum changes for CCE in Danish lower secondary schools. However, some changes that affect the CCE whole school approach are worth considering even though they have remained largely unnoticed. In hindsight they seem to form a consistent policy that decreases the attention paid to the democratic influence of teachers and students. Claims about the Danish CCE whole school approach often refer to the Education Act, which states that the school must be "marked by" freedom of spirit, equal worth, and democracy. This statement has changed from previous versions of the Act (1975 and 1993), which in stronger terms claimed that the "teaching and entire daily life of the school must be founded on the freedom of spirit, equal worth and democracy" (emphasis added; Thejsen 2009).

Another remarkable change is a weakening of the democratic influence of teachers. This began with the 1990 abolition of the Teachers' Council (consisting of all teachers and the school leadership with a teacher chairman). It was replaced by a Pedagogical Council with less decisionmaking authority (Christensen and Olsen 2013a; Vestergaard 1996; Skovgaard-Petersen 2018). Also, in 1990 the School Committee (skolenævn) was abolished and replaced by a School Board (skolebestyrelse) strengthening the influence of the school principal and parents (Recommendations for the Folkeskole Act, columns 5174 and 5175, in Lovforslag $\mathrm{nr} . \mathrm{L}$ 215, 1989). It is widely believed that the abolition of the Teachers' Council was an attempt to weaken teacher influence on school management (Madsen 2015). In the Folkeskole reform 2013, the mandatory Pedagogical Council was made voluntary with a similar intent (Christensen and Olsen 2013b).

In 2007 a law discontinued a mandatory subject in teacher education called "the school in society." The purpose of the subject was to enhance incoming teachers' understanding of the societal role of the school in a democracy from historical and contemporary perspectives (Simonsen 2004). According to Hedegaard et al. (2011), the subject was popular and received highly positive assessments from external examiners. At present there is no specific subject in teacher education that introduces the basic political/democratic dimension of the school as an institution in society.

In 2007, the solution was to replace "the school in society" with "citizenship" as a new third dimension of the then existing subject "Christianity and life-enlightenment" (Hedegaard et al. 2011; EVA 2003). However, in 2012/2013 "Christianity, life-enlightenment and citizenship" was in danger of being discontinued. For many educators the crux of this subject is the tradition of progressive education and "Bildung." So, the ministry's move stirred protests (by highly esteemed scholars and both left and right political parties). It survived in teacher education but in a somewhat less important role (Rømer 2018; Lund 2012; Kemp 2013). The subject is somewhat controversial because, in the view of its proponents, it represents important Danish values and traditions. However, in the view of critics, this is irrelevant. In an era with multicultural trends and an increasing emphasis on global dimensions of citizenship these national and cultural dimensions in teacher education have diminished relevance.

A Danish tradition, which for many years was considered of vital importance for the Folkeskole, is the so-called "class teacher." The concept refers to the practice that one teacher of a class has the responsibility for the social life and wellbeing of students, for coordinating activities, pedagogical issues, and teaching plans with other teachers, for planning meetings with parents, and for coordination with the school principal regarding matters related to the class. This class teacher would know all the individual students and their parents (and vice versa) from their very first day at school and be able to closely follow the development of each student throughout all years of schooling. This tradition was changed and partly abolished as part of a major Folkeskole 
reform in 2013. In this reform, the class teacher is no longer necessarily a specific pivotal person with assigned responsibilities. On the contrary, the tasks and responsibilities of the class teacher are re-defined as so-called "functions" that the school principal may assign in different ways and in different school years to various teachers and/or other pedagogical staff.

Interestingly, the role of the class teacher was the sole topic of a 1996 book by the Ministry of Education (supported by eight educational experts), because the role of the class teacher had been strengthened by law in 1993. The very first sentence states: "In the Danish Folkeskole, the class teacher is still pivotal as the person creating the best possible conditions for the individual class and the individual student, both in academic and social matters" (Ministry of Education 1996, p.7). It is remarkable that this key role has been discontinued after numerous decades when it was a hallmark of Danish schooling practices (Bramming et al. 2009; Christiansen 2009).

Furthermore, for many years, the class teacher's tasks were linked to the so-called "class hour" (Skole og forældre n.d.), which secured specific extra time for social activities and discussions intended to promote social cohesion among classmates. The class hour was established in 1975. It was considered unique for the Folkeskole as a way of promoting democratic processes in class. For example, the class representative in the Student Council would have ample time to discuss issues and proposals without disturbing lessons. This could provide an opportunity to introduce praxis in deliberative democracy and strengthen student participation. This activity was also abolished as part of the Folkeskole reform 2013 (Christiansen 2017; Kristensen 2010).

Changing the role of the class teacher and abolishing the class hour are significant because both these phenomena were previously regarded as strong democratic features of the Folkeskole. Abolishing them seems to entail a change of mindset (Dall 2013). It is undoubtedly the case that the political intention was to dispense with allegedly ineffective activities perceived as closely linked to the values of progressive education introduced in legislation in the mid-1970s. In a famous (some might call it infamous) speech in the Danish Parliament (October, 2003) the then Prime Minister, Anders Fogh Rasmussen, claimed that there were far too many student discussions taking place in the Folkeskole in circles that were based on uninformed opinions. Since then, the word "circle-education" has been used as a depreciatory characterization of progressive education (Statsministeriet 2003).

This political statement and the changes mentioned earlier can be seen as symptoms of an education policy trend toward focusing on measurable school effectiveness and academic outcomes. In this perspective, the class is a learning community in need of a teacher performing professional class "leadership" or "management," rather than a social community where the teacher needs to be present as a person in ongoing discussions. In other words, the developments mentioned above can be viewed as changes to the scope of the school that indirectly also influence civic education (see some further discussion later in this chapter).

\section{A Brief History of the Reception of the Results from Danish CIVED and ICCS}

In 2000, before the CIVED 1999 results were announced, nobody expected Danish students to perform particularly well in an international comparative study. Previous results in other subject areas from TIMSS 1995 and PISA 2000 placed Danish students close to the international averages in mathematics and reading. In general, the results were interpreted as mediocre and below expectations.

In the CIVED 1999 study (Torney-Purta et al. 2001), the average scale score of the Danish students on the cognitive student test was very close to the international average. However, this was interpreted relatively positively, because most of the better-performing countries had tested grade 9 students, whereas Denmark had tested grade 8 . The international variation was 
rather complex. The two highest average test scores were from countries that had tested grade 8 students whereas the next five listed countries had tested grade 9 students. Foreseeing this grade issue, some countries (including Denmark) tested both grade 8 and an additional sample at grade 9. In Denmark, grade 9 students performed much better than grade 8 students in the cognitive test. The average score for grade 9 students was on par with the very best performing countries. It was important for Denmark to consider the grade issue, because, at the time, social science was a mandatory subject only in grade 9. Given this additional information about the CIVED cognitive test results, the overall interpretation of the Danish results was relatively positive and the introduction of the mandatory grade 9 social science course was put forward as a likely explanation for the substantial difference between grade 8 and grade 9 .

In other areas of CIVED (concerning students' attitudes towards democracy and intentions to participate in political activities) results were similar for grades 8 and 9. This was illuminating, because, in theory, it would have been more advantageous to investigate grade 9 in ICCS, given that grade 9 is the last year of lower secondary school for the majority of students in Denmark. However, an interesting finding was that grade 9 students were significantly more positive than grade 8 students about the so-called "open classroom climate" (for discussion) in lessons that concern CCE. When answering these IEA questions, grade 9 students would be thinking of social science whereas grade 8 students would be thinking of lessons in history or Danish.

At the international level, the Danish results concerning students' attitudes and intentions to participate varied substantially across different content dimensions. For example, the Danish average support for gender equality was the highest of all countries, and the percentage of Danish students expecting to vote at national elections was among the highest in Europe (more than 90\%). Other results were not as good. For example, the Danish students' endorsement of participation in less traditional forms of political activities and activism as well as support for various citizen actions was very low. In most cases, the relative strengths and weaknesses of the Danish results were quite similar to those of the other Nordic countries.

When first announced, the results of CIVED 1999 received widespread public attention (a press conference in the Ministry of Education and television, radio, and written press coverage). The broader context for the announcement was the (alleged) poor results from other international studies, so there was a feeling of relief when the CIVED 1999 results were released. The results were interpreted relatively positively but did not spark extensive debate.

In ICCS 2009, the average Danish student test score was significantly above the international average (Schulz et al. 2010). Another important finding was that the Danish boys had the highest average of boys from any country. The test result received some celebratory media attention, including some remarkable headlines about the Danish students as "World champions in democracy" (Ebdrup 2010). However, the public attention was lessened because the international findings were (pre)released during the summer holidays, and holding a press conference proved unrealistic. When the final full results were released in late 2010, the results were no longer "breaking news." Another problem was that the media's attention (and the attention of the Ministry of Education) was being drawn to the unexceptional results from PISA 2009, released the same month. Nevertheless, the celebratory media attention and headlines about civic education endured for a significant amount of time. Once more, the results about students' attitudes and intentions to participate in various activities revealed both relatively high and low Danish scores in the international comparisons. For example, of all countries the Danish students had the most positive perception about the open classroom climate for discussion, one of the highest averages regarding gender equality, and the highest percentage in Europe on a question about the intention to vote in national elections. However, results in other areas were much lower, especially for almost all other kinds of active political participation. For example, Denmark had the lowest average of all countries on a scale regarding "social movement related citizenship" 
and one of the lowest averages on a scale measuring student' perceptions of influence at school (Bruun 2010a; 2010b; Bruun and Lieberkind 2011; 2012; 2013; 2014)

In ICCS 2016, the Danish average knowledge test result was once more at the top of the official country list. The release of the main results (November 2017) received fairly strong media coverage and considerable subsequent interest (Bruun et al. 2017a; 2017b; 2017c; 2018a; 2018b). In general, the reception of ICCS 2016 has been focused on the attitudinal dimensions of the study. This new focus is probably due to changes in the broader societal context where the importance of democratic principles and values increasingly is viewed as paramount due to phenomena such as left and rightwing populism, lack of trust in democratic institutions, internet surveillance, increasing inequity, the climate crisis, and migration issues. In this context, the relatively low average scores for various types of political participation among Danish youth have gained new attention as stronger citizen engagement and higher levels of political participation among youth are regarded as possible ways to mitigate a crisis in democracy.

\section{Impact, Cooperation, Networks, and Activities}

In the Danish context, a challenge is that much of the (potential) impact of ICCS is indirect. In general terms, users of ICCS reports and results may include students, teachers, parents, ordinary citizens, media specialists, school principals, non-governmental organizations, policymakers, educators, and researchers. These groups do not necessarily share the same interests or points of view about CCE and/or the results of ICCS. Therefore, Danish ICCS-reports are written in such a way that insights and results are kept open for different interpretations according to the interests of these different actors. Also, any policy impact needs to be seen in the context of education policy in general during the 20 year period from 1999 to 2019. Even when the "scientific evidence" of a specific ICCS-result meets the highest standard, its implications remain open for both pedagogical and political discussion.

From the very beginning of CIVED to ICCS 2016, our contacts and mutual interests with colleagues, especially from the other Nordic countries, have been essential. In CIVED, Ingrid Munck (Swedish International Steering Committee Member) organized meetings designed to establish a Nordic network for the national CIVED research teams. These meetings continued on a more or less regular basis in ICCS 2009 and ICCS 2016, especially in the Scandinavian countries. For example, the process of adapting and translating the instruments in ICCS 2009 included a close cooperation between the Danish, Norwegian, and Swedish teams. This improved the comparability of data by finding mutual solutions to difficult adaptation or translation issues. Another area of cooperation has been the Scandinavian contribution to development of new content areas and/or items for national, Scandinavian, or general international use. Various initiatives have evolved in broader contexts from this network. An important event was a conference about the ICCS 2009 results in Oslo, Norway, in 2012. This was made possible thanks to Rolf Mikkelsen (NRC) and Dag Fjeldstad from the Norwegian ICCS 2009 team at Oslo University, cooperating with the Nordic Council of Ministers and the Norwegian Ministry of Education (see Fjeldstad and Mikkelsen 2013). Another event was the conference Nordic Education in a Democratically Troublesome Time at Örebro University, Sweden, in 2018. The conference was organized by Örebro University (Erik Amnå), the Nordic Council of Ministers, and the Swedish Ministry for Education and Research. Nordic contributions about ICCS were included in a seminar, chaired by Cecilia Arensmeier. A special reason for mentioning these two conferences is that both included teachers, teacher educators, and policy advisors in order to increase their awareness of results and potential impact.

In general, the periods in between study cycles have been important for research and other activities with potential impact. From a Danish point of view, this type of indirect impact by means of knowledge sharing is very important. However, it can be challenging to fully develop 
these activities, both within and across countries; the several national ICCS teams do not always have the time and funding to participate.

CIVED/ICCS results are intended to reach diverse target groups, but public servants from various parts of the Ministry of Education are especially important readers of these results. Occasionally, we have had the opportunity to brief Ministry of Education staff. The extent of such briefings varies depending on the interest expressed by the ministry and the relevance of results. Results from ICCS are used by both national and international departments in the ministry and regularly included as documentation in reports. There are few examples of the CIVED/ICCS results having direct political impact. However, we have always believed that the difference between the Danish grade 8 and 9 test results in CIVED 1999 (discussed earlier) may have influenced the ministerial decision to introduce social science as a subject in grade 8 . This, incidentally, may partly explain the improved Danish grade 8 test results in ICCS 2009

ICCS results are becoming disseminated increasingly widely in Denmark in areas such as university courses, social science teacher training, youth networks, and associations working with CCErelated matters (human rights, global citizenship, minority groups, and so forth).

\section{The Framing of CCE in Different Discourses}

During the first decades of the 21st century, the most persistent and fierce educational debates in Denmark have dealt with the implementation of a range of political agendas and reforms other than directly CCE-related ones. This is in stark contrast to preceding years and decades where heated debates about democracy in schools and other aspects of civic education were very common. Nevertheless, some of the more general political initiatives and reforms, especially during the timespan of ICCS 2009 and ICCS 2016, may be interpreted as having indirect implications for the school as a place for CCE. The main idea behind this section is to give some examples by focusing on conflicts between different educational ideologies and discourses. In 2004, the OECD conducted a review of the Danish school system where the final report included a long list of specific, and in many cases controversial, policy recommendations (OECD 2004) about schools' effectiveness, accountability, benchmarks, and national school monitoring systems. From 2005 to 2013 numerous political reforms were introduced, along the lines of the OECD recommendations. Noteworthy examples include: 1. Establishing a "Culture of Evaluation" (at student, teacher, and school levels); 2. Regular annual student tests by the Ministry of Education; 3. Strengthening school leadership; and, 4. Longer school days.

Policymakers found inspiration from New Zealand, Canada, the United States, and England in areas such as visible learning, evaluation tools, action plans for the individual student, strong school leadership, school effectiveness frameworks, and accountability systems (Christensen 2015; Kolff 1999; Olsen 2006; Liv i skolen 2015; Liv i skolen 2017).

In 2013, a fierce conflict broke out between Danish teachers and their employers (i.e., the Union of Municipalities, supported by the government ${ }^{2}$ ). An increase in teachers' working hours (one of the OECD recommendations) had been put into place by the government by abolishing the then collective agreement defining teachers' working hours and other working conditions. It was an open secret that the increase in working (teaching) hours was critical for financing other changes being made to the Folkeskole at the same time (Christensen 2013a, 2013b; Jensen and Jørgensen 2013)

In general, Danish educational policy from 1999 to 2018 was characterized by New Public Management (NPM) (Hultqvist et.al 2018; Krejsler 2013a, 2013b; Krejsler et al. 2018). This

2 In Denmark, government interference in such matters is unusual and controversial. As a general rule, wages and working conditions are defined in collective agreements agreed upon by the trade unions and employers' organizations where the state plays no part. This is known as "The Danish Model'" (Lykketoft 2010). 
can be viewed as a part of a general transformation of the welfare state into a competitive state and of the nation state into a global state (Pedersen 2011; Biesta 2011). As a part of this transformation, schools are expected to become effective and productive by competing. They must also be held accountable for their competitiveness. The NPM theoretical assumption is that the public sector (the school) will become more productive once it is forced to adapt to conditions that resemble those of private companies in competitive markets. Each school is expected to view itself as an actor in a quasi-school-market in which all schools, teachers and students comply with the same given standards (national tests and benchmarks), and make their results measurable and accountable (Bogetoft et al. 2014).

From a CCE point of view, it is interesting that NPM perceives the individual as a "user" or "customer" guided by self-interest in her or his relationship to the state and the school system. In other words, the role of the democratic citizen is transformed into something similar to consumer choice (Aberbach and Christensen 2005). This also implies that the task of the school in preparing students for their future life as citizens of society changes in scope. In NPM, the citizen is a rational economic individual driven by self-interests. Policymakers can rely on the fact that the citizens will strive to optimize their individual and personal gain by making rational choices.

This line of thinking is in opposition to the values behind the Danish tradition of progressive education inculcating civic virtue and treasuring shared values, and norms (i.e., in short, the citizen as a member of a community and a national culture). In the late 20th century, the Danish Public School was officially characterized in terms of a community, by an absence of competition and as relying on a sense of solidarity. Many of these ideas found their way to Denmark from abroad (for example, from the Dewey tradition). However, the ideology of progressive education has always also resonated well with a long Danish tradition of idealizing "the living word" (a famous expression in Denmark from N.F.S. Grundtvig, 1783-1872) (Larsen 2018).

For advocates of this progressive tradition, the true meaning of the school is a place where a sense of community is practiced and experienced, especially in the classroom as a place for common deliberation. Here students (ideally) have an equal voice in relationships based on reason, honesty, and mutual respect. As such, the main focus is on the citizen as a member of civil society in a given cultural and local context. This contrasts with NPM ideology, in which the productive and effective citizen is first of all characterized by an accumulation of individual self-interests and personal competencies in order to become competitive in the workplaces and marketplaces of a globalized economy.

From the point of view of advocates of the neo-liberal competitive state, the idealization of the deliberative and/or communitarian citizen is counter-productive and conservative (even nationalistic or populistic). From the neo-liberal point of view, the progressive ideal is a conservative ideology that fails to promote an up-to-date and adequate globally competitive citizenry.

This conflict permeates current educational discourse, educational practice, educational research, and educational political debate. In general, the Folkeskole in Denmark has become a veritable public discursive battlefield concerned with the classical conflict between civic education as academic achievement (for future work) and as civic/moral education (for future life). In general, the conflict is articulated as a conflict between productive and progressive education. Proponents on both sides present the conflict as insurmountable in political, ideological, and scientific discourses. By agreeing to disagree, each side of the conflict keeps itself alive by keeping the opposing view alive. 


\section{ICCS and the Future}

The international study centers behind CIVED and ICCS have been commendable in their efforts to include the interests and perspectives of the national centers in the ongoing development of the study. Nevertheless, it might be worthwhile to consider further strengthening of international cooperation at the NRC level. This cooperation could take place during studies but also between study cycles in order to widen the cross national and regional exchange of ideas and the implementation of the use of data in secondary analysis and follow-up research and development. There are constraints of funding and time, but it would be appropriate for ICCS to initiate discussion in this area. With this in mind, study cycles could be implemented less frequently. This would address another problem, namely the difficulty of recruiting schools to participate. There are a vast number of studies, surveys, and tests taking place. From a broader point of view, it might be fruitful to lengthen the study cycle by one year so that the first year after the release of the international main results could remain an active year with study management and NRC meetings. This would give both the international and national centers more time for analyses and further cooperation.

Most likely, the issue of sustainable societies for a sustainable future will have a very strong and lasting effect on the perception and definition of civic and citizenship education in the decades to come. Looking forward to ICCS 2022, the initiative to cooperate with UNESCO on various aspects of global citizenship and education for sustainable development may become of special importance for the study going forward.

From a scientific point of view, the future of ICCS is bright. The continued accumulation of data over the decades of study cycles is unique and unrivalled in this area of research. The longterm insight to be gained from CIVED and the ICCS cycles is already beginning to be widely recognized and will no doubt prove to be extremely important. The founding mothers (and fathers) should be proud.

\section{References}

Aberbach, J.D., \& Christensen, T. (2005). Citizens and consumers. An NPM dilemma. Public Management Review, 7(2), 225-246.

Allerup, P., Torre, A., \& Hetmar, V. (2012). LEKS-longitudinal. En undersøgelse af uddannelsesforløb for unge, der i 2007 gik ud af 9.klasse i de københavnske folkeskoler. Copenhagen, Denmark: Danmarks institut for uddannelse og pædagogik, Aarhus Universitet. http://edu.au.dk/fileadmin/edu/Udgivelser/ LEKS_2012.pdf

Amadeo, J.-A., Torney-Purta, J., Lehmann, R., Husfeldt, V., \& Nikolova, R. (2002). Civic knowledge and engagement: An IEA study of upper secondary students in sixteen countries. Amsterdam, the Netherlands: International Association for the Evaluation of Educational Achievement (IEA).

Arendt, K., Baunkjær, K., \& Rangvid, B. (2017). Skolebestyrelsesformænds oplevelser af skolen i folkeskolereformens tredje år. Kommenteret tabelrapport. Copenhagen, Denmark: Det nationale forskningsog analysecenter for velfærd.

Biesta, G.J.-J. (2011). Learning democracy in school and society. Rotterdam, the Netherlands: Sense Publishers.

Bramming, B., Kampp, J., \& Nyegaard, P. (2009). Klasselæreren. Copenhagen, Denmark: Forlaget Tellus. Bogetoft, P., Heinesen, E., \& Tranæs, T. (2014). The efficiency of educational production: A comparison of Denmark with other OECD countries. The Rockwool Foundation Research Unit Study Paper No. 71. Odense, Denmark: University Press of Southern Denmark.

Bruun, J. (2001). Politisk dannelse - unges synspunkter på demokratiske værdier i skole og samfund. Copenhagen, Denmark: Danmarks Pædagogiske Institut.

Bruun, J., Johansen, J., \& Allerup, P. (2003). Gymnasieungdommens politiske dannelse. Copenhagen, Denmark: Danmarks Pædagogiske Universitets Forlag.

Bruun, J. (2010a). ICCS 2009, Internationale hovedresultater. Copenhagen, Denmark: Danmarks Pædagogiske Universitetsskole, Aarhus Universitet. 
Bruun, J. (2010b). ICCS 2009, Det europæiske modul. Copenhagen, Denmark: Danmarks Pædagogiske Universitetsskole, Aarhus Universitet.

Bruun, J., \& Lieberkind, J. (2011). Unges politiske dannelse. En sammenfatning af ICCS 2009 (Brief report). Copenhagen, Denmark: Danmarks Pædagogiske Universitetsskole, Aarhus Universitet.

Bruun, J., \& Lieberkind, J. (2012). ICCS 2009, De danske elever. Copenhagen, Denmark: Aarhus Universitet. Bruun, J., \& Lieberkind, J. (Eds.). (2013). Unge, globalisering og politisk dannelse. Copenhagen, Denmark: U-press.

Bruun, J., \& Lieberkind, J. (Eds.). (2014). Challenges of citizenship education. A Danish case study. Copenhagen, Denmark: U-press.

Bruun, J., Lieberkind, J., \& Schunck, H.B. (2017a). ICCS 2016. Internationale hovedresultater. (Preliminary report). Copenhagen, Denmark: Danmarks institut for Pædagogik og Uddannelse, Aarhus Universitet.

Bruun, J., Lieberkind, J., \& Schunck, H.B. (2017b). ICCS 2016. Det europæiske modul (Preliminary report). Copenhagen, Denmark: Danmarks institut for Pædagogik og Uddannelse, Aarhus Universitet.

Bruun, J., Lieberkind, J., \& Schunck, H.B. (2017c). ICCS 2016. Udvalgte hovedresultater (Preliminary report). Copenhagen, Denmark: Danmarks institut for Pædagogik og Uddannelse, Aarhus Universitet.

Bruun, J., Lieberkind, J., \& Schunck, H.B. (2018a). Unge, skole og demokrati (Final national report). Aarhus, Denmark: Aarhus Universitetsforlag.

Bruun, J., Lieberkind, J., \& Schunck, H.B. (2018b). Skolen og fremtidens borgere. En sammenfatning af ICCS 2016. Copenhagen, Denmark: Danmarks institut for Pædagogik og Uddannelse, Aarhus Universitet.

Christensen, E. (2013a). Ombudsmanden: Det virker planlagt. Copenhagen, Denmark: Folkeskolen.dk. https://www.folkeskolen.dk/528584/ombudsmanden-det-virker-planlagt

Christensen, E. (2013b). Professor: Her indrømmer Corydon skinforhandlinger. Copenhagen, Denmark: Folkeskolen.dk. https://www.folkeskolen.dk/526851/professor-her-indroemmer-corydon-skinforhandlinger

Christensen, E., \& Olsen, J.V. (2013a). Lærer: Vi kan ikke undvære pædagogisk råd. Copenhagen, Denmark: folkeskolen.dk. https://www.folkeskolen.dk/524264/laerer-vi-kan-ikke-undvaere-paedagogisk-raad

Christensen, E., \& Olsen, J. V. (2013b). Al magt til lederne. Copenhagen, Denmark: folkeskolen.dk. https:// www.folkeskolen.dk/524259/al-magt-til-lederne

Christensen, P.B. (2015). Canadisk skolemodel kan inspirere. Copenhagen, Denmark: altinget.dk. https:// www.altinget.dk/uddannelse/artikel/canadisk-skolemodel-kan-inspirere

Christensen, T.S. (2015). Fagdidaktik i samfundsfag. Frederiksberg, Denmark: Frydenlund.

Christiansen, J.P. (2017). Hvor blev klassens time af? Copenhagen, Denmark: folkeskolen.dk. https://www. folkeskolen.dk/612093/hvor-blev-klassens-time-af

Christiansen, H. (2009). Klasselæreren. Copenhagen, Denmark: folkeskolen.dk. https://www.folkeskolen. dk/60598/klasselaereren

Dall, C. (2013). Forligspartier gør op med klasselæreren. Copenhagen, Denmark: Information.dk. https:// www.information.dk/indland/2013/06/forligspartier-goer-klasselaereren

Ebdrup, N. (2010). Skolen gør danske elever til verdensmestre i demokrati. Copenhagen, Denmark: Videnskab.dk. https://videnskab.dk/kultur-samfund/skolen-gor-danske-elever-til-verdensmestre-idemokrati

EMU. (n.d.). Prøveformen i samfundsfag og historie. Copenhagen, Denmark: Undervisningsministeriet (Ministry of Education). https://arkiv.emu.dk/modul/pr\%C3\%B8veformen-i-samfundsfag-og-historie

EMU. (2017). Samfundsfag (Social Science). Copenhagen, Denmark: Undervisningsministeriet (Ministry of Education). https://www.emu.dk/omraade/gsk-1\%C3\%Abrer/ffm/samfundsfag

EVA (2003). Læreruddannelsen. Copenhagen, Denmark: Danmarks Evalueringsinstitut.

Faulks, K. (1998). Citizenship in modern Britain. Edinburgh, United Kingdom: Edinburgh University Press. Fjeldstad, D., \& Mikkelsen, R. (2013). Demokrati og lærerbevissthet. Acta Didactica Oslo, 1/2013 (pp. 1-280). Oslo, Norway: Institutt for lærerutdanning og skoleforskning.

Henningsen, I., \& Allerup, P. (2017). PISA-matematik. Holdninger og fakta. Nordby, Denmark: Forlaget Matematik.

Hedegaard, K. M., Simonsen, S., \& Rasmussen, T. N. (2011). De pædagogiske fags rolle i læreruddannelsen - i et internationalt og komparativt perspektiv: Et udviklingsarbejde ved Læreruddannelsen i Aarhus, 2010 - 2011. Aarhus, Denmark: VIAUC Læreruddannelsen i Aarhus. 
Hultqvist, H., Lindblad, S., \& Popkewitz, T.S. (Eds.). (2018). Critical analyses of educational reforms in an era of transnational governance. Cham, Switzerland: Springer.

Jacobsen, R., Bjørnholt, B., Andersen, M., \& Jordan, A. (2017). Lærere og pædagogers oplevelse af den længere og mere varierede skoledag i folkeskolereformens tredje år. Kortlægning, 2017. Copenhagen, Denmark: Det nationale forsknings- og analysecenter for velfærd.

Jensen, J., \& Jørgensen, H.B. (2013). Knockout. Fortællingen om lærerlockouten. Copenhagen, Denmark: Folkeskolen.

Jensen, V., Kjer, M., \& Skov, P. R. (2017). Skoleledernes oplevelser af skolen i folkeskolereformens tredje år. En kortlægning. Copenhagen, Denmark: Det nationale forsknings- og analysecenter for velfærd.

Kaare, J. (2006). Naturen er gledet ud af samfundsfag. Copenhagen, Denmark: folkeskolen.dk. https:// www.folkeskolen.dk/43632/naturen-er-gledet-ud-af-samfundsfag

Kemp, P. (2013). Modstandere af KLM-faget spiller ikke med åbne kort. Kristeligt Dagblad, February 12, 2013. https://www.kristeligt-dagblad.dk/debat/modstandere-af-klm-faget-spiller-ikke-med-\%C3\%A5bnekort

Koch, H. (1945). Hvad er demokrati? (1995). Copenhagen, Denmark: Gyldendal.

Kolff, W. (1999). New Zealand er stadig in. Copenhagen, Denmark: folkeskolen.dk. https://www.folkeskolen. dk/6136/new-zealand-er-stadig-in

Kreiner, S. (2011). Is the foundation under PISA solid? A critical look at the scaling model underlying international comparisons of student attainment. Research report 11/1. Copenhagen, Denmark: Department of Biostatistics, University of Copenhagen. https://ifsv.sund.ku.dk/biostat/biostat annualreport/images/c/ca/ResearchReport-2011-1.pdf.

Kreiner, S., \& Christensen, K.B. (2014). Analyses of model fit and robustness. A new look at the PISA scaling model underlying ranking of countries according to reading literacy. Psychometrika, 79(2), 210-231.

Krejsler, J. B. (2013a). Jagten på den kompetente elev til det globale videnssamfund - Om transnational videnspolitik, lærerprofessionalitet og skoleudvikling. In J. Bruun, \& J. Lieberkind (Eds.), Unge, globalisering og politisk dannelse (pp. 177-196). Copenhagen, Denmark: U-press.

Krejsler, J.B. (2013b). What works in education and social welfare? A mapping of the evidence discourse and reflections upon consequences for professionals. Scandinavian Journal of Educational Research, 57(1), $16-32$.

Krejsler, J.B., Olsson, U., \& Petersson, K. (2018). Becoming fit for transnational comparability. Exploring challenges in Danish and Swedish teacher education reforms. In H. Hultqvist, S. Lindblad, \& T.S. Popkewitz (Eds.), Critical analyses of educational reforms in an era of transnational governance (pp. 93-112). Cham, Switzerland: Springer.

Kristensen, M.K. (2010). Slut med klassens time. arbejderen.dk, December 10, 2010. https://arbejderen. dk/artikel/2010-12-10/slut-med-klassens-time

Larsen, E. (2018). Det levende ord. Om Grundtvig. Copenhagen, Denmark: Lindhardt and Ringhof.

Liv i Skolen. (2017). Angelsaksisk didaktik. (2017,1). Aarhus, Denmark: VIA Højskolen for Videreuddannelse og Kompetenceudvikling.

Liv i Skolen. (2015). Canadisk pædagogik i skolen. (2015,1). Aarhus, Denmark: VIA Højskolen for Videreuddannelse og Kompetenceudvikling.

Lovforslag nr. L 215 (1989). Forslag til lov om ændring af folkeskolen. http://skole-foraeldre.dk/artikel/ lovgivning

Lund, R. (2012). Hvorfor KLM i læreruddannelsen? Copenhagen, Denmark: folkeskolen.dk. https://www. folkeskolen.dk/512606/hvorfor-klm-i-laereruddannelsen

Lykketoft, M. (2010). The Danish Model - a European success story. Copenhagen, Denmark: AE-Economic Council of the Labour Market.

Madsen, V. (2015). Nedkæmpelsen af lærerne. Copenhagen, Denmark: folkeskolen.dk. https://www. folkeskolen.dk/574860/nedkaempelsen-af-laererne

Ministry of Education. (1996). Klasselæreren - koordinering af arbejdet. Copenhagen, Denmark: Ministry of Education (Undervisningsministeriet).

Ministry of Education. (2006). Rapport fra udvalget til styrkelse af samfundsfag i folkeskolen. Copenhagen, Denmark: Ministry of Education (Undervisningsministeriet). https://www.ft.dk/samling/20051/almdel/ udu/bilag/431/293699.pdf 
Ministry of Education. (2008). Learning Democracy. Copenhagen, Denmark: Ministry of Education (Undervisningsministeriet). https://www.uvm.dk/publikationer/engelsksprogede/2008-learning-democracy Ministry of Education. (2017a). Mock elections. Copenhagen, Denmark: Ministry of Education (Undervisningsministeriet). https://uvm.dk/aktuelt/nyheder/uvm/2017/jun/170615-skolevalg-fortsaetter Ministry of Education. (2018a). Vejledning til folkeskolens prøve med selvvalgt problemstilling i historie, samfundsfag og kristendomskundskab - 9. klasse. Copenhagen, Denmark: Ministry of Education (Undervisningsministeriet).

Ministry of Education. (2018b). Vejledning for faget samfundsfag. Copenhagen, Denmark: Ministry of Education (Undervisningsministeriet).

Ministry of Education. (2018c). Mandatory Topics (outside subjects). Copenhagen, Denmark: Ministry of Education (Undervisningsministeriet). https://uvm.dk/folkeskolen/fag-timetal-og-overgange/fag-emnerog-tvaergaaende-temaer/obligatoriske-emner

Ministry of Education. (2018d). Mandatory Cross Subject Themes. Copenhagen, Denmark: Ministry of Education (Undervisningsministeriet). https://uvm.dk/folkeskolen/fag-timetal-og-overgange/fag-emnerog-tvaergaaende-temaer/tvaergaaende-temaer

Nielsen, C., Keilow, M., \& Westergaard, C. (2017). Elevernes oplevelser af skolen i folkeskolereformens tredje år. En kortlægning. Copenhagen, Denmark: Det nationale forsknings- og analysecenter for velfærd.

Olsen, J.W. (2006). Skole på den amerikanske måde. Copenhagen, Demark: folkeskolen.dk. https://www. folkeskolen.dk/41878/skole-paa-den-amerikanske-maade

Organisation for Economic Co-operation and Development (OECD). (2004). Reviews of national policies for education: Denmark 2004. Lessons from PISA 2000. Paris, France: OECD Publishing. https://www.oecdilibrary.org/education/reviews-of-national-policies-for-education-denmark-2004_9789264017948-en

Pedersen, O.K. (2011). Konkurrencestaten. Copenhagen, Denmark: Hans Reitzels.

Petersen, A., Uljens, M., \& Sommer, D. (2018). Fremtidsparat? - hinsides PISA - nordiske perspektiver på uddannelse. Copenhagen, Denmark: Hans Reitzels.

Retsinformation. (2014). Bekendtgørelse om elevråd i folkeskolen [Students' council consolidation Act]. Copenhagen, Denmark: Ministry of Education (Undervisningsministeriet). https://www.retsinformation. dk/Forms/R0710.aspx?id=163972

Retsinformation. (2017). Folkeskoleloven [Folkeskole Act]. https://www.retsinformation.dk/forms/R0710. aspx?id=196651

Riise, A.B, Ravn, K., \& Lauritzen, T. (2018). Nationale test efter tre reform-år: Fortsat ingen fremgang. Copenhagen, Denmark: folkeskolen.dk. https://www.folkeskolen.dk/644925/nationale-test-efter-trereform-aar-fortsat-ingen-fremgang

Rømer, T. (2018). Læreruddannelsens opgør med læreruddannelsen (Private blog). May 13, 2018, Thomas Aastrup Rømer. http://www.thomasaastruproemer.dk/laereruddannelsens-opgoer-medlaereruddannelsen.html

Schulz, W., Ainley, J., Fraillon, J., Kerr, D., \& Losito, B. (2010). ICCS 2009 international report: Civic knowledge, attitudes and engagement among lower secondary school students in thirty-eight countries. Amsterdam, the Netherlands: International Association for the Evaluation of Educational Achievement (IEA).

Schulz, W., Ainley, J., Fraillon, J., Losito, B., \& Agrusti, G. (2016). IEA International Civic and Citizenship Education Study 2016: Assessment framework. Cham, Switzerland: Springer. http://www.springer.com/gp/ book/9783319393568.

Schulz, W., Ainley, J., Fraillon, J., Losito, B., Agrusti, G., \& Friedman, T. (2018a). Becoming citizens in a changing world. IEA International Civic and Citizenship Education Study 2016 international report. Cham, Switzerland: Springer. https://doi.org/10.1007/978-3-319-73963-2

Simonsen, S. (2004). Skolen i samfundet skal bestå. Copenhagen, Denmark: folkeskolen.dk. https://www. folkeskolen.dk/30010/skolen-i-samfundet-skal-bestaaalbeit

Sjøberg, J. (2018). Reform uden den store effekt. Copenhagen, Denmark: folkeskolen.dk. https://www. folkeskolen.dk/628356/reform-uden-den-store-effekt

Sjøberg, S. (2014). PISA - syndromet - Hvordan norsk skolepolitikk bliver styrt av OECD. Nytt Norsk Tidsskrift, 31(1). https://www.idunn.no/nnt/2014/01/pisa-syndromet_-_hvordan_norsk_skolepolitikk_ blir_styrt_av

Skole og forældre (n.d.). Klassens tid. http://skole-foraeldre.dk/artikel/klassens-tid 
Skovgaard-Petersen, V. (2018). Lærerråd (in: Den Store Danske). København: Gyldendal. http://den storedanske.dk/index.php?sideld=119723

Statsministeriet (2003). Statsminister Anders Fogh Rasmussens tale ved Folketingets åbning tirsdag den 7. oktober 2003. Copenhagen, Denmark: Statsministeriet. http://www.stm.dk/_p_7446.html

Struwe, K. (1977). Samtidsorienterings tilblivelse. Årbog for Dansk Skolehistorie. Copenhagen, Denmark: Selskabet for Dansk Skolehistorie. https://uddannelseshistorie.dk/wp-content/uploads/2020/08/a-1977kamma-struwe.pdf

Styrelsen for IT og Læring. (2019). Notat om kompetencedækningen i folkeskolen 2018/19. Copenhagen, Denmark: Ministry of Education (Undervisningsministeriet). https://www.uvm.dk/-/media/filer/uvm/stat/ pdf19/191011-notat-om-kompetencedaekningen-i-folkeskolen-2019.pdf?la=da

Thejsen, T. (2009). Kampen om folkeskolens formål. Copenhagen, Denmark: fokeskolen.dk. https:// backend.folkeskolen.dk/ /Documents/41/55841.pdf

Torney-Purta, J., Lehmann, R., Oswald, H., \& Schulz, W. (2001). Citizenship and education in twenty-eight countries: Civic knowledge and engagement at age fourteen. Amsterdam, the Netherlands: International Association for the Evaluation of Educational Achievement (IEA).

Torney-Purta, J., Schwille, J., \& Amadeo, J.-A. (Eds.). (1999). Civic education across countries: Twenty-four national case studies from the IEA Civic Education Project. Amsterdam, the Netherlands: International Association for the Evaluation of Educational Achievement (IEA).

Vestergaard, J. (1996). Blæsten går frisk. Copenhagen, Denmark: folkeskolen.dk. https://www.folkeskolen. dk/24808/blaesten-gaar-frisk

Open Access This chapter is licensed under the terms of the Creative Commons Attribution-NonCommercial 4.0 International License (http://creativecommons.org/licenses/by-nc/4.0/), which permits any noncommercial use, sharing, adaptation, distribution and reproduction in any medium or format, as long as you give appropriate credit to the original author(s) and the source, provide a link to the Creative Commons license and indicate if changes were made.

The images or other third party material in this chapter are included in the chapter's Creative Commons license, unless indicated otherwise in a credit line to the material. If material is not included in the chapter's Creative Commons license and your intended use is not permitted by statutory regulation or exceeds the permitted use, you will need to obtain permission directly from the copyright holder. 